\title{
Problems of international payments
}

\author{
Sanskriti Singh ${ }^{1}$, Aishwarya sharma ${ }^{2}$ \\ I (College of legal studies / University of petroleum \& energy studies, India) \\ ${ }_{2}^{2}$ (College of legal studies / University of petroleum \& energy studies, India)
}

\begin{abstract}
Hundreds of thousands of international payments are made every second of everyday by businesses. Business-to-business payments are primarily associated with supplier payments related to the import of goods and services.

Despite the potentially large number of international payments associated with international trade and commerce, the process of transmitting money cross borders remain extremely complex, not just in terms of routing payments but also in terms of handling and passing payments between stake holders in the transaction chain (correspondents).

Since International payments involve contacts with at least two different states and their respective legal system, it is intuitive that they raise issues of conflicts of laws. Anybody even superficially familiar with private international law would be quick to realize that such issues are bound to be numerous and complicated. Yet it is surprising that, despite the number of international payments made each day around the world and the likelihood of disputes liable to raise conflicts problems, both the case laws and literature on these issues are quite scarce and this is what author shall seek to answer by the end of this paper.
\end{abstract}

Keywords: International payments, private international law, cross borders, international trade and commerce, conflict of law

\section{MEANING OF INTERNATIONAL PAYMENTS-}

Hundreds of thousands of international payments are made every second of everyday by businesses. Business-to-business payments are primarily associated with supplier payments related to the import of goods and services. According to world trade organization estimates, global imports were approximately GBP 13 trillion to GBP 15 trillion $^{1}$ in 2009 , and while most e-commerce transactions are domestic, approximately $15 \%$ are made by overseas buyers ${ }^{2}$. Despite the potentially large number of international payments associated with international trade and commerce, the process of transmitting money cross borders remain extremely complex, not just in terms of routing payments but also in terms of handling and passing payments between stake holders in the transaction chain (correspondents). There is also regulatory complexity, which differs by jurisdiction. No wonder this seemingly simple process goes wrong so often and costs more than it should.

\section{HISTORY AND EMERGENCE OF INTERNATIONAL PAYMENTS}

Defined as the instruction to transfer funds between payer and payee bank accounts or institutions located in different countries ${ }^{3}$, international payments have come a long way since the lengthy negotiations over quantities of gold that occur more than two thousand years ago from traveler's letters of credit exchanged in the earliest days of international travel or commercial trading. The state of modern international payments landscaped is largely a result of two major series of events in the twentieth century- the aftermath of World War II and the rise of technology. In 1959 the first banking industry computer, which read cheques through MICR(Magnetic Ink Character Recognition), came into use. 9 years later in 1968 the Inter-bank Computer Bureau (which became Back in 1971) where the electronic transfer of funds between banks possible. Finally, in 1973 the Society For Worldwide Inter Bank Financial Telecommunication(SWIFT) was formed with the intention of creating a standards format and language for international financial transactions via a share global data processing and communication links. The first Swift message was sent in 1977. As a result of these technological developments, and many more since, international payments have become an integral part of business for many companies worldwide. However, due to the additional complexities associated with different laws, currencies and time zone, unique payment facilities and processes have been introduced by financial institutions to cater for cross border transfer.

\footnotetext{
${ }^{1}$ Cross-border payment perspective report, glanbrook partners, 2011

2 IBID

${ }^{3}$ Bollen, R., history and operations of international payment system,(SSRN 2007)
} 


\section{III. international organizations for international payments}

Business to business cross border payments can be made using several different methods and should be a relatively straight forward part of trading internationally. However, many businesses- up to $34 \%$ - encounter long payment delay, payment failures and fund seizures, due to avoidable mistakes ${ }^{4}$. This mistakes impact business service levels, competitiveness and profitability, which means it is important for businesses to eliminate them to ensure they deliver efficient payments. Keeping caused, risk and errors to a minimum and remaining in control of the international payment process must be a priority for organizations in today's economic climate. The most significant international payment methods involves the banks that utilize the SWIFT messaging service, specialist foreign exchange provider, and the Single Euro Payments Area(SEPA). However, some of these methods are not without their challenges. Banks, while convenient to use, they tend to charge a higher fee for each transaction, plus an extra administration charge. Moreover, the fee the banks charge for the payment to be processed within 3 days if often considerable higher than a fee levied for a payment taking 3 or more days. If the European Parliament is successful in pushing through planned new regulation to ensure bank to bank SWIFT transfer are made within 2 days, it will be a significant step forward for international payment. SEPA retains the potential to be a very positive development in the European payments market. Unfortunately, it is currently suffering from low uptake amidst the instability of the current economic climate and banks are refocusing there attention. There are also various security concerns, a general lack of awareness about SEPA and low business and public sector uptake. Whilst foreign exchange provider have a strong global presence, such organizations have historically been in the business of cross-currency trading for the consumer market rather than processing commercial payments.despite the fact forex $(\mathrm{FX})$ providers are not banking institutions, some complies with Financial Services Authority Regulations and have an efficient solution to facilitate cross border payments, service delivery, specialist knowledge, and transparency of transaction seize as well as beneficiary management is key advantages that some of the independent providers can offer over the competitors. However, within enterprises, payments tend to be integrated into much broader cash management solutions, which is possibly where the banks attempt to differentiate themselves.

\section{CONFLICT OF LAWS AND LEGAL PROBLEMS}

Since International payments involve contacts with at least two different states and their respective legal system, it is intuitive that they raise issues of conflicts of laws. Anybody even superficially familiar with private international law would be quick to realize that such issues are bound to be numerous and complicated. Yet it is surprising that, despite the number of international payments made each day around the world and the likelihood of disputes liable to raise conflicts problems, both the case laws and literature on these issues are quite scarce ${ }^{5}$. With international payment system are related different risks, from which are most distinguished the risk of territory and the exchange rate risk:

1. THE RISK OF TERRITORY-also called political risk- is the risk of laws when investing in a given country cause by changes in a country political structure or policies, such as tax laws, tariffs, expropriation of assets, or restriction in repatriation of profits. For example, company may suffer from such loss in case of expropriation or tightened foreign exchange repatriation rules or from increased credit risk if the government exchanges policies to make it difficult for the company to pay creditors.

2. EXCHANGE RATE RISK- is simply the risk to which investors are exposed because changes in exchange rate may have an effect on investments that they have made. The most obvious exchange rate risk are those that results from buying foreign currency denominated investment. The commonest of these are shares listed in another country or foreign currency bonds. Investors in company that have operation in another country, or that export, are also exposed to exchange rate risk. A company with operation abroad will find the value in domestic currency of its overseas profit changes with exchange rate.

\section{The Legal Problems Of International Payment-}

For the purpose of this analysis an international payment is one of two types of transactions. The first type, called a credit transfer in the terminology of the UNCITRAL model law ${ }^{6}$. This is the transaction whereby funds are transferred at the initiative of one party (originator) to continue to use the model law's terminology to another party(beneficiary) through one or more bands or other financial intermediaries.

a. The second type of international payment is a debit transfer, where the payment is made in accordance with an order given by the beneficiary for the payment of the holder of the payer's funds in accordance with the

\footnotetext{
${ }^{4}$ Data sourced from travelle's payment help cheque results(http://www.travllexbusiness.com/uk/payment-help-cheque)

${ }^{5}$ CseeEvra Corporation v. Swiss Bank Corporation, 522 S.S upp. 820 n.d.III

${ }^{6}$ UNCITRAL model law on international credit transfer adopted by the united nations commission on international law on may $15^{\text {th }}, 1992$. The adoption of legislation based on the model law formed the object of recommendation of a general assembly of the united nations dated $15^{\text {th }}$ nov. 1992 .
} 
prior authorization by the payer. In other words a credit transfer is debtor- initiated, whilst a debit transfer is creditor-initiated.

However, there is one very significant difference. Also with regard to domestic payment the rule and solutions may not necessarily be clear, but there is at least certainty as regards to the legal system within which they are to be sort, this being obviously the one of the country with which the payment has its only contact .even this certainty is lacking with regard to international payments. Since there is no single set of rules dealing(automatically or prima-facie) with all international payments, or for that matter with any given international payment, at least in theory each payment can be analyzed from the perspective of more than one legal system. The consequence is that there is no single solution to any of the problems. It is thus obvious that whatever attempt to seek the solution of any specific legal problem arising from an international payment must be preceded by conflicts of laws analysis aimed at identifying the legal system or systems against the backdrop of which the payment is to be viewed. Despite these scarce attention devoted to it, perhaps because of its apparent abstruseness, private international law plays a central role in context of international payments.

\section{Understanding International Payments With Latest Case Laws-}

1) EXPORT-In the case of Aromaic Overseas Company B $\boldsymbol{V}$ In $\boldsymbol{r e}^{7}$, it had been decided that any and every person who is some way or the other facilities purchased by a non-resident for the purpose of export cannot be brought within the ambit of clause (b) of explanation 1 to 9 (1)(i). When assesses receives only net proceeds as per export invoice, there is nothing further left over to be treated as income received or to be received or accrued or deemed to be accrued or arising in India or outside India ${ }^{8}$. The profits from the offshore supply contracts held not to be liable to tax in India on the ground that the transfer of title in the goods has passed outside India. As no operations qua the agreement for supply of equipment were carried outside India, no income can be deemed to have occurred or arisen in India whether directly or indirectly or through any business contracts in India'

2) UNDERWRITING COMMISSION- In the case of Mahindra and Mahindra Ltd ${ }^{10}$, it had been held that underwriting commission had paid to lead managers to issue of global depository receipts by Indian party, are business profits which are not taxable in absence of permanent establishment in India. There were no reimbursement of expenses and no element of profit and hence was not taxable. Similar decision was given in DY DIT v Tata Iron \& Steel Co Ltd, where it had been held that services rendered by non-resident lead managers to the assesse company for bringing out GDR issue, though in the nature of technical or managerial services, were not "made available" to the assesses and therefore cannot be taxed in India. Underwriting commission was nither fees for technical services under section 9 (1)(iv) nor chargeable to as "business profits" under article 7 of DTAA in the absence of any PE of the non-resident in India, payment towards reimbursement of expenses not being in the nature of income was not taxable.

3) SUPPLY OF EQUIPMENT /RAW MATERIAL- Offshore supply of equipment is not liable to tax in India though it is a part of composite contract involving onshore service component. Similar view was given in the case of DY DIT $v$ Daimler Chrysler A. $\boldsymbol{G}^{11}$, where it was held that sale of raw material /CKD units to DCIL. DCIL carried out further activity of assembling the same and selling the finished cars. There were no further activities carried out by the assesses in India in this connection. Mere sale of raw materials / components would not result in business connection and even if it did as per the terms and conditions of the contract between the accesses and DCIL, no income occurred to the assesses on the basis of any activities carried out on behalf of the assesses in India. Mere existence of subsidiary does not by itself constitute the subsidiary company as a PE of the parent. The DCIL was merely rendering a very insignificant auxiliary / preparatory service in the sale of CBU cars by assesses to the Indian Clients. Therefore DCIL did not constitute a dependent agent of the assesses. In the case of Director of Income Tax vs. LG Cable Ltd. ${ }^{12}$ It was held that considerations for the offshore supply of equipment by the assesses, a Korean company, to an Indian company cannot be deemed to have accrued or arisen in India as the terms of the agreement stipulated transfer of title/ property in the goods as soon as the goods were loaded in the ship at the port of shipment i.e. outside India, and there is no material to show that the accrual of income from this sale was attributable to any operations carried in India or that the PE of the assesses in India had any role to play in the offshore supply of equipment. Consideration paid to foreign company was only for supervising the erection of machines which cannot be said to payment of assembly of machines to fall within the exclusion clause of Explanation 2 to section 9(1)(vii), However , as persons who rendered services were not present in

\footnotetext{
${ }^{7}$ AAR no. 825 of 2009

${ }^{8}$ ITO v. vishaljanakkumaraggarwal

${ }^{9} \mathrm{D}$ y . CIT v. lg cables ltd.

${ }^{10} 313$ ITR 263

1139 SOT 418

12237 CTR 438
} 
India foe the required number of days as envisaged by article 5(j) of the DTAA read with article 13(5), income was chargeable to tax in India and there was no obligation to deduct tax at source on such payment. ${ }^{13}$ Non-resident company is not liable to tax in India in respect of payment of off shore supply of equipments under the composite contracts for setting up transmission lines and consequently, no tax is required to be deducted at source for the payment made to it for the supply of equipments. ${ }^{14}$ In the contract of the kind undertaken by the assesses, if there is a composite consideration, the same can be conveniently segregated in different components. I $\mathrm{f}$ the profits from supply contract are held to be taxable separately, as the supply is the milestone in the whole contract then the treatment meted out to profits on sale of equipment and consideration received for supply of software will have to be different, as the two assets are of different nature involving different profit abilities . The A.O. bifurcated in the ratio of $30: 70$. As the assesses was unwilling to give the details the bifurcation made by the A.O. was justified. ${ }^{15}$

4) HOTEL- Assessed running business of Hotel payments to US based interior Landscaping consultants M. Work done by $\mathrm{M}$ is basically inspection of hotel .reviewing of the facilities, comparing the same with M's standards and suggesting improvements / change wherever required to $M$ standard, which did not amount to technical services and therefore no tax was deductible at source. Similarly, fees paid by UK company A was also for work of design, documentation and did not fall under article 13 of Indo- UK DTAA, likewise ,fees paid to Thailand company BD , for rendering services of landscape architectural consultancy was not assessable in India. ${ }^{16}$

5) FREIGHT OF CARGO- In view of article 9 (1) of DTAA between India and UK, freight income earned by non- resident assesses on account of transportation of cargo in international traffic by ships operated by other enterprises under slot chartering, arrangements would be taxable only in state of residence and consequently, such income would be exempt from taxation under Indian Income Tax Law. ${ }^{17}$ AAR in the case of Seabird Exploration FZ LLC, UAE, In re ${ }^{18}$ it was held that mere physical presence of nonresident's vessel in territorial waters of India pursuant to hiring of vessel on Bareboat Charter terms by applicant does not, without anything more, constitute a permanent establishment. Where agreement was executed outside India and delivery of vessel also took place outside India by reason of mere presence of vessel in India without violation of VPC, source of income cannot be said to be located in India and to this extent, hire charges paid by the applicant are liable to be excluded from taxable profits of VPC.

\section{CONCLUSION}

THEREFORE, the present conflict rules can be interpreted so as to provide a workable solution to the problem of the law governing international payments. It remains nevertheless indisputable that - although the situation is probably no more serious than with respect to certain other types of complex international transactions which are equally fraught with conflicts of laws problems - this solution is not particularly satisfactory, at least from the viewpoint of legal certainty and even more so from that of the overall consistency of the regime of the rights and obligations of all the parties involved.

One should not underestimate the fundamental role that can be played in the elimination of conflicts simply by appropriate and well drafted arrangements which address the issues at a contractual level, notably in the context of payment and clearing mechanism. Clearly contractual arrangements are incapable of solving all problems, and particularly those falling outside the scope of lexcontractus (typically the effects of insolvency, of blocking orders, and such likes). These issues however are hardly likely to be resolved by harmonization, since even the bravest attempts of harmonizing the conflicts of law of international payments cannot be expected to deal with more than lexcontractus, and would thus leave all other matters to unharmonized national conflicts system. All this might contribute to reduce the scope of problems of conflict of laws in the area of international financial transactions which, to revert to initial question, are indeed quite intractable and could thus be a bonanza for litigators generally, and more specifically for conflicts lawyers. Considering the actual lack of litigation on these issues pointed to at the outset of this paper, the reduction of potential conflicts through substantiveharmonization might be in practice not be as disappointing to conflict lawyers as could otherwise be expected, whilst at the same time contributing to the elimination of some - but by no means all- of the legal risks of international payments.

There is no doubt that the payments landscape of tomorrow will look very different to how it does today and that the outdated payment models of yesterday will be replaced by newer, more automated and efficient models. The future landscape will be driven by the need to make payments faster, more securely and

\footnotetext{
${ }^{13}$ Aditya Viral Nuvo Ltd. V. ASST CIT, 56 DTR 100

${ }^{14}$ Deepak Cables(India) ltd., 242 CTR 469

${ }^{15}$ Raytheon Company v. DCIT, 62 DTR 1

${ }^{16}$ ASST CIT v. VICEROY Hotels Ltd., 60 DTR 1

${ }^{17}$ Balaji Shipping(UK) ltd., 121 ITD 61

18 192 TAXMANN 471
} 
more remotely than ever before. Both bank and non-bank institutions will need to focus on improving the services they already offer in terms of pricing, integrating , transaction routing, file management and reporting, as well as finding innovative ways to cater for the latest payment industry trends, particularly online and mobile payment processing. The new model of B2B payments will be characterized by a many-to-many environment, on-demand services real- time payments via secure networks, with transparency of pricing and improved service levels throughout the supply chain. The evolution already witnessed in the B2C payments market provides the B2B world with somewhat of a blueprint for progress, a world driven by growth in e-commerce and the rise of the social networking phenomenon. The winners will need to have trusted, secure and the global industrial payment methods, coupled with the simple, convenient and multi-choice aspects of the b2b payments world.

In order to take advantage of the opportunities described, banks need to adapt to the convenience, simplicity, multi-access channel world, and use outsourcing opportunities and partnering for technological expertise, something which may require them to adopt a culture change. The meteoric rise of social networking will surely shift the payments landscape, as payment institutions and banks seek to facilitate faster and more accurate to keep up with the next generation. For now, it is payment institutions that are drivers of innovation, capitalizing on these new markets, creating "many-too-many" and peer-to peer flexible payment solutions that embrace converging technologies.

International payment processing needs to evolve. As the International Payments Survey ${ }^{19}$ shows, it is way behind domestic payments processing in terms of speed and ease of use and, as the remit driving SEPA states, the aim is for individuals and companies to be able to make international payments "as easily , efficiently and safely as they can make the today at the national level " ${ }^{20}$. If this can be achieved, companies worldwide will be able to conduct their future business at a faster rate and in a less stressful financial environment.

In terms of , the SEPA system is already having an impact, albeit only for the banks, which are able to make international funds transfers as inexpensively as their domestic transfers because "price difference between cross- border and national payments in euro were eliminated in $2001 " .{ }^{21}$ However, whilst this is a step in the right direction, the European Commission (EC)'s work is far from over, as corporate are not actively engaged in the SEPA change program or convinced yet of its benefits.

When the EC finally manages to implement the new, simpler SEPA regulations into the world of business, it is likely that international payments will no longer be viewed as a hassle that those involved could do without. Away from SEPA, the pressure is on banks and foreign exchange providers to make their services as easy to use as possible in line with the results of our survey ${ }^{22}$ in which $81 \%$ of respondents voted convenience and ease of use as the most important aspect when making international payments.

\section{REFERENCES}

Websites-

[1] https://www.boq.com.au/EIBHelp/NT_FX001Help.htm

[2] www.smarta.com/advice/.../how-to-manage-international-payments

[3] www.freshbusinessthinking.com/business_advice.php?AID=1012

[4] articles-

[5] 210.40.80.25:8082/uploadfiles/gjjs/xtj/3.doc

\footnotetext{
${ }^{19}$ International payments survey(ALBANY software \& financial-i)

${ }^{20} \mathrm{http}$ ///europa.eu/rapid/pressreleasesaction.do?reference=MEMO-09-383\&format=HTML\&aged=0\&language=EN\&guilanguage=en

${ }^{21}$ IBID

${ }^{22} \mathrm{http}$ ///europa.eu/rapid/pressreleasesaction.do?reference=MEMO-09-383\&format=HTML\&aged=0\&language=EN\&guilanguage=en
} 